\title{
Effects of External and Internal success factors on SMEs performance in emerging economies: Evidence from Saudi Arabia
}

Hend Sameh Hafez Hassan

Mansoura University Faculty of Commerce, Egypt;

AOU, Kuwait 


\begin{abstract}
Purpose -The aim of this study's to examine the influence of external and internal factors that are claimed by the literature to affect Small and Medium Enterprises SMEs' performance. The literature is relatively rich in this regard with several published researches, but the contribution of the current study is primarily related to the emerging economies context in general and the Saudi Arabian SMEs sector in particular.

Methodology / design / approach - The study uses a quantitative approach based on a structured questionnaire that is administered to a convenient sample consisting of 142 SMEs.

Findings - The findings revealed that all of the six proposed factors (independent variables) are significantly influencing the SMEs performance (dependent variable). Legal \& Administrative Factors (LAF)is found to have the strongest relationship with performance.

Research Limitation / future research recommendations -The study is applied in Saudi Arabia, therefore the results generalisation should be treated with caution. Arab, Muslim, and other conservative societies are likely to generalise the findings of this study to their own context. Future studies are encouraged to extend this study to other countries, use qualitative research methods to induce knowledge, and/or examine the mediating / moderating effect of other variables.

Practical implications -Several implications for practitioners and entrepreneurs emerge. The study elects a group of success factors that the literature suggests and puts them to empirical examination to assess their validity. The study is conducted in Saudi Arabia, taking into consideration the aspects that influence small enterprises' success.

Originality / value - Numerous studies have contributed to the development of SMEs conceptualisation, and many studies have examined the success and failure factors that affect SMEs. Having said that, noticeable scarcity of studies examining SMEs' success factors in developing countries and in Saudi Arabia in particular elaborates the contribution and value of the study.
\end{abstract}

Keywords SMEs; Performance; Internal \& External Success Factors; Entrepreneurship; Saudi Arabia

Paper type Research Paper. 
ملخص

الغرض - تهدف هذه الدراسة إلىشراسة تأثير العوامل الخارجية والداخلية التي يزعم أنها تؤثر على أُماء الثركات الصغيرة والمتوسطة. الأكبيات غنية نسبياً في هذا الصشد مع العديد من الأبحاث المنشورة، ولكن مساهمة الدراسة الحالية تتعلق بشكل أساسي بسياق الاقتصئدات الناشئة بشكل عام وقطاع الثركات الصغيرة والمتوسطة في المملكة العربية السعوثية على وجه الخصوص. المنهجية / التصميم / المنهج - تستخدم الدراسة منهجًا كميًا يعتمد على استبيان منظم يتم إثلارته على عينة ملائمة تتكون من 142 شركة صغيرة ومتوسطة. التتائج - كشفت التتائج أن جميع العوامل الستة المقترحة (المتغيرات المستقلة) تؤثر بثكل كبير على ئماء الثركات الصغيرة والمتوسطة (المتغير التابع). تم العثور على العوامل القانونية والإثلارية لايها أقوى علاقة مع الأكاء.

الحد من البحث / توصيات البحوث المستقبلية ـ يتم تطبيث الدراسة في المملكة العربية السعوثية، لذلك يجب تعميم نتائج البحث بحذر. من المرجح أن تقوم المجتمعات العربية والإسلامية والمجتمعات المحافظة الأخرى بتعميم نتائج هذه الدراسة على سياقها الخاص. يتم تشجيع الدراسات المستقبلية على مد هذه الدراسة إلى بلان أخرى، واستخدام طرق البحث النوعي للحث على المعرفة، و / أو شراسة التأثير الوسيط / المتوسط للمتغيرات الأخرى. الآثار العملية ـ تظهر آثار متعهدة على الممارسين ورجال الأعمال. تتتخب الدراسة مجموعة من عوامل التجاح التي تقترحها الأكبيات وتضعها في الامتحان التجريبي لتقييم صلاحيتها. تم إجراء الاراسة في المملكة العربية السعثية، مع مراعاة الجوانب التي تؤثر على نجاح المشروعات الصغيرة.

الأصالة / القيمة ـ ساهمت العديد من الاراسات في تطوير مفهوم الثركات الصغيرة والمتوسطة ، وثرس العديد من الدراسات عوامل النجاح والفشل التي تؤثر على الشركات الصغيرة والمتوسطة. وبعد قولي هذا، فإن ندرة الدراسات التي تبحث عوامل نجاح الثركات الصغيرة والمتوسطة في البلان التامية والمملكة العربية السعوثية على وجه الخصوص توضح مساهمة وقيمة الدراسة. الكلمات المفتاحية أثداء؛ عوامل النجاح الداخلية والخارجية؛ ريثدة الأعمال. المملكة العربية 


\section{Introduction}

Factors the affect the success or failure of Small and Medium Enterprises (SMEs) and entrepreneurships have drawn attention of scholars and practitioners over the past (Baporika et al, 2016; Keeble $\boldsymbol{e} t$ al., 1992). The SMEs sector contributes to the economic growth and development in any given country, and to the global economy as a whole in terms of GDP, job creation, combating unemployment, and businesses diversification. Nevertheless, examining the performance of SMEs reveals that there exists a variation in defining these factors.

Several factors contribute to the success or failure of SMEs. Apparently, there is no consensus on the exact manifest of factors. This is due to the differences in geo-demographic characteristics of any given SME, for example, human capital; knowledge \& expertise; internal \& external 
market factors such as attaining finance \& grants; governmental support; the uncertainty towards external environment; in addition to gender-specific attributes that may affect the success and prosperity of a SME.

2. Overview of Saudi Arabian Small and Medium Enterprise Business Sector

Saudi SMEs are accounted for about85\% of the national registered companies, and $45 \%$ of employment. Therefore, SMEsplaya significant role in Saudi's future plans. SMEs are estimated to contribute about one-third of the country's GDP 33\%, higher than several other GCC countries (www.jeg.org.sa).

With lower oil prices, and the endeavours to diversify the Saudi economy, it is increasingly important to enhance the private sector's contribution to GDP by advancing the SME sector. Nevertheless, even with the efforts to improve the quality of the business environment, Saudi SME ssuffer from complicated managerial and regulatory measures, weak performance, poor abilities in talent acquisition, and difficulty to raise fund. Saudi SMEs raise only (5\%) of the total funding, which is a small proportion compared to global rates (www.monshaat.gov.sa). This is due to several reasons, including:

1. The lack of available and trustworthy data about these enterprises,

2. The lack of legal framework that allows for collateral registry and legal enforcement in case of non-payment,

3. Most SMEs lack audited accounts, which in turn burden lenders with greater resources and time in serving these SMEs,

4. More than $80 \%$ of SMEs are single owner entities, making it difficult to differentiate between private assets and the company's assets. 
The former reasons pinpoint why funding SMEs in Saudi is a risky business, which in turn highlights the essential need for policies that communicate assurance and trust to the lenders. Literature Overview

- Success factors

The literature of SMEs includes a vast amount of publications. Nevertheless, a great discrepancy as to which variables lead to the success of SMEs indicates that there is currently no comprehensive theory of success factors of SMEs performance (Lussier \& Halabi, 2010; Halabi \& Lussier, 2014; Lussier et al., 2016). Models of success factors date back to the late 1980s when scholars such as Reynolds \& Miller (1989), Cooper et al., (1990), and Lussier (1995) offered valuable contributions to this research stream.

Robert Lussier's model (1995; 1996a;b); Lussier \& Pfeifer (2000) has been a robust model of SMEs success factors as it was validated in several countries around the world, such as USA; Croatia; Israel; and Chile. The model was based on detailed analysis of relevant literature in order to understand the reasons behind the success or failure of business ventures. Lussier's model lists as much as ten (10) variables that contribute to the success or failure of SMEs:

6. Education;

7. Staffing;

8. Product life cycle stage;

9. Partners; and

10.Marketing knowledge.
1. Capital;

2. Record Keeping \& financial control;

3. Business experience;

4. Management experience;

5. Business plan;

Other studies examined the success factors of enterprises in terms of demographic characteristics of the entrepreneur i.e. gender (e.g. Elenurm 
\& Vaino, 2011; Ramos et al., 2014; Nneka 2015). Hasan \& Almubarak, (2016) electas much as eight (8)factors in their empirical investigation of the factors influencing women entrepreneurs' success in Bahrain. These factors have been categorised by Shane (2003); and Hasan \& Almubarak, (2016) into internal and external factors and included:

1. Entrepreneurial orientation (Internal);

2. Human capital (Internal);

3. Entrepreneur goal \& motivations (Internal);

4. Industry characteristics (External);

5. Economic factors (External);

6. Socio-cultural factors (External);

7. Legal \& administrative factors (External); and

8. Opportunity recognition (mediator variable).

Furthermore, Chiun Lo et al., (2016) offer five (5) factors that lead to successful performance of Malaysian SMEs, these are:

4. Technology orientation; 1. Top management support; and

2. Customer focus;

5. Entrepreneurial

3. Employee orientation; orientation.

Other studies have suggested rather behavioural and psychological approach to investigate factors influencing SMEs performance (Hankinson et al., 1997; Baum et al., 2001; Gomezelj \& Kusce, 2013). Personal characteristics (traits of the entrepreneur) are claimed to influence the success and prosperity of the enterprise. Factors such as the founding reasons of the business and personality traits of the owner have been examined by Gomezelj \& Kusce (2013). Additionally, they also 
identified several environmental factors (e.g. social; cultural; political; and economic) that contribute to the success or failure of the SMEs.

- Organisational performance

Organisational Performance (OP) is an important concept that has been put into investigation for several decades. Improving organisational performance is the ultimate goal for managers. For scholars, investigating different ways to enhance organisational performance has been an important research objective. $O P$ can simply be classified into financial and non-financial performance (Perez \& Canino, 2009; Gomezelj \& Kusce, 2013; Chiun Lo et al., 2016). While financial indicators of business performance have gained greater consensus among academics and practitioners in terms of their ability to reflect an organisation's success, yet in the SMEs context, it is unfair to use only financial indicators to judge a business's success (Gomezelj \& Kusce, 2013). The reason is that most of young SMEs in their early years of operations achieve poor financial results due to paying high interest rates and baring higher costs. However, that does not mean they are failures (Perez \& Canino, 2009).

Gomezelj \& Kusce (2013) simply put success of the SME as the achievement of goals and objectives as they were set. They further categorize the performance of the business into two (2) main groups: the business performance, and the personal performance and satisfaction of the entrepreneur. The latter is rather a 'softer' indicator of success and includes personal satisfaction at work; customer satisfaction; independence; and life style. The former refer to the classic financial indicators of $\mathrm{OP}$. 
More recent studies, such as Chiun Lo et al., (2016, pp. 372) identified organisational performance as "the concept that measures a firm's position in the market place and the firm's ability in meeting its stakeholders' needs". They also refer to (Slacket al., 2010) notion of organisational performance as the degree to which the operation fulfils the performance objectives (primary measures), and meets the needs of the customers (secondary measures). Financial indicators of business performance have traditionally included financial ratios such as Return on Assets (ROA); Return on Investment (ROI); and Return on Equity (ROE).Kaplan \& Norton have suggested as early as (1996) that a more balanced approach to assess organisational performance should be followed by including both financial and non-financial performance measures (i.e. Balanced Scorecard methodology). The non-financial measures currently include customer base; internal business processes; and learning \& growth measures.

The study of Hasan \& Almubarak (2016) has followed a rather balanced approach to measure female entrepreneurs' performance. Financial measures included sales and profits growth, whereas nonfinancial measures focused on indicators such as increased employees numbers; period of operation (length of survival); the capability of supplying quality products; new product development ability; labour productivity; and CSR (Corporate Social Responsibility).Prior studies noted that the success features differ among different economies (Benzing et al., 2009; Lewrick et al., 2011; Zamberi \& Xavier, 2012; Lussier et al., 2016).

Accordingly, the current study aims to extend prior examination of success factors of SMEs into a new context that has been under 
researched. It is therefore the aim of this study to examine the influence of internal and external success factors on SMEs performance. These factors as categorised by Hasan \& Almubarak, (2016) are of particular importance to this study, and there for are hand-picked from the vast relevant literature for the following reasons:

1. These factors have already been developed and validated by earlier studies (i.e. Shane, 2003, Gomezelj \& Kusce (2013), and Hasan \& Almubarak, 2016),

2. As explained in the subsequent conceptual framework section, the dependant variable of SME's performance is claimed by various literature streams to be influenced by a wide array of factors that cannot be all included in this study due to its limitations. Therefore electing a set of variables that cover the internal and external environmental forces is a rather useful approach to answering the study's question (i.e. How do the claimed internal and external success factors influence the performance of SMEs in Saudi Arabia?".

3. The Saudi context is similar in many facets to Bahrain context where the earlier study of Hasan \& Almubarak, (2016) was conducted; which in turn gives the author the opportunity to compare and contrast her findings to those of the earlier study in order to support and enrich existing knowledge, or modify and suggest new insights,

4. The elected six factors generically represent most of the success factors noted within relevant literature. For example the 'internal' Human Capital (HC) factor that this study adopts as one of the internal success factors clearly covers other relevant factors illustrated individually by other scholars such as: education, experience (management experience, business experience), marketing knowledge. 
Similarly, the 'external' Legal \& administrative factors (LAF) encompass the political, economic, regulatory and legislative forces that influence SMEs performance.

\section{Research Question}

This study is primarily concerned with answering the question "How do the claimed internal and external success factors influence the performance of SMEs in Saudi Arabia?"

In order to provide a sound answer to this question, a thorough analysis of relevant literature is undertaken to identify the study's independent variables (success factors). Business success criteria are several, but for the purpose of the current empirical investigation, financial measures in the form of sales and profits growth, whereas non-financial measures focused on indicators such as increased employees numbers; period of operation (length of survival); the capability of supplying quality

products; new product development ability; labour productivity; and CSR (Corporate Social Responsibility).

\section{Conceptual Framework}

The study adopts the former theoretical models of Shane (2003), and Hasan \& Almubarak (2016) with some modifications. In this regard, six (6) independent variables (success factors) are suggested to positively influence the SME performance (dependent variable) (Figure 1), these factors are categorised into internal factors (i.e. EO, HC, EGM) and external factors (i.e. EF, SCF, and LAF).

1. Entrepreneurial orientation (EO);

2. Human capital (HC);

3. Entrepreneur goal \& motivations (EGM); 
4. Economic factors (EF);

5. Socio-cultural factors (SCF), and

6. Legal \& administrative factors (LAF).

\section{Figure 1: Conceptual Framework}

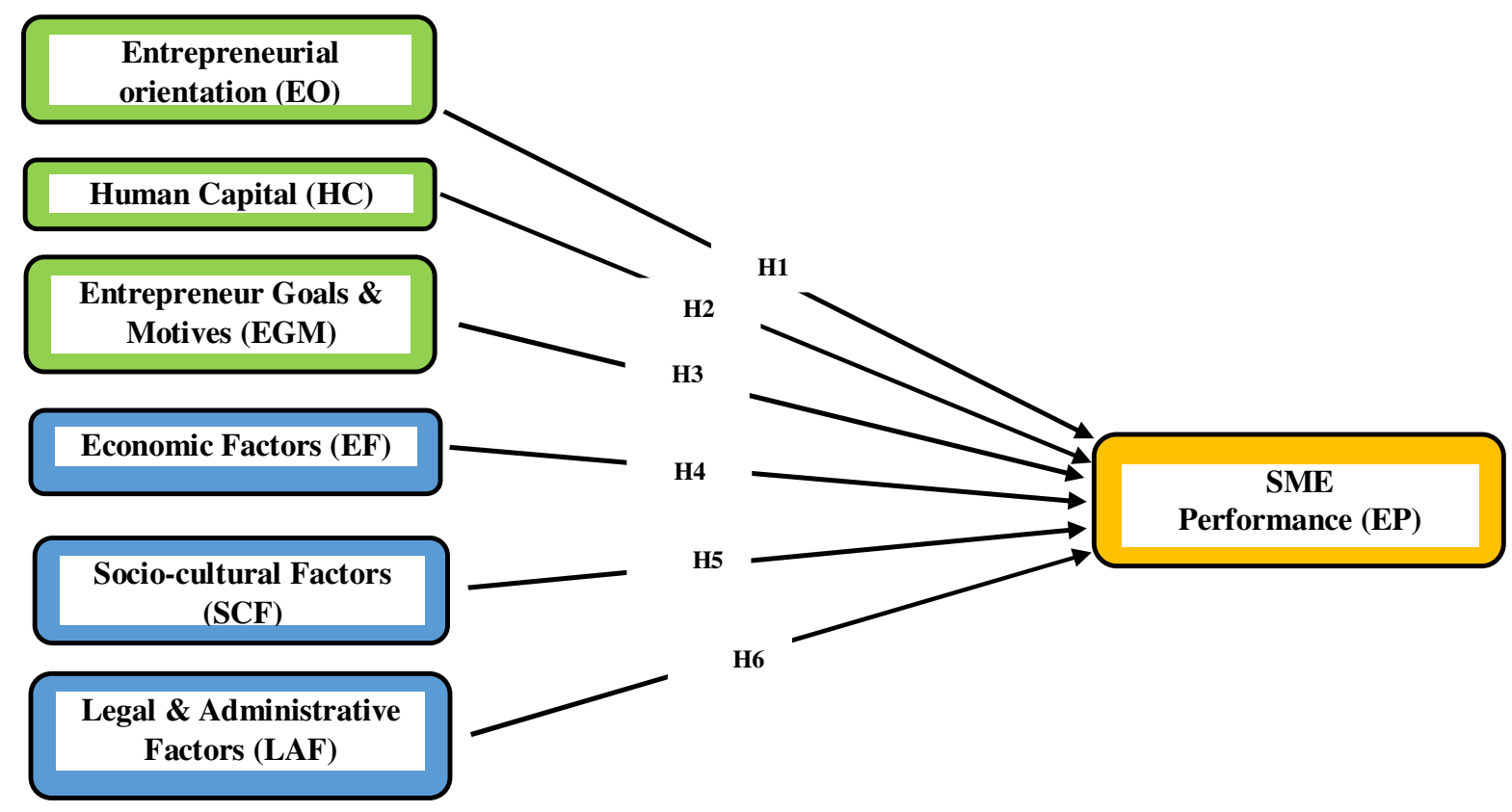

\section{Research Hypotheses}

The study proposes six (6) hypotheses as discussed below:

Entrepreneurial Orientation and SMEs Performance: entrepreneurial orientation could be referred to as "the extent to which a business owner is inclined to take business-related risks, to favour change and innovation to obtain competitive advantage for the SME, and to compete aggressively with other firms" (Hasan \& Almubarak, 2016, p.85). Shane (2003) defined entrepreneurial orientation as the ability of the entrepreneur to discover and use opportunities associated with entrepreneurial performance, which in turn varies amongst business owners and is based on the distinct conditions concerning risk 
acceptance. Risk averse individuals are less likely to exploit business opportunities that might bear risks. On the contrary, entrepreneurs who are more likely to take risks to capture business opportunities are more likely to succeed as a result of gaining competitive advantages; adopting innovative and creative solutions; and in turn achieve improved business performance. Consequently, the following hypothesis is put forward for validation:

H1: There is a significant relationship between Entrepreneurial

\section{Orientation and SMEs performance}

Human Capital and SMEs Performance: human capital is an important organisational resource. Based on education and experience of workers, SMEs gain significant knowledge that affects different aspects of business performance. Issues such as identifying and taking advantage of opportunities; developing core competencies and sustaining competitive advantages are few examples of how valuable human capital could 'make or break' the successful implementation of plans that aim to improve business performance and achieve success. As a result, the next proposition is formulated:

H2: There is a significant relationship between Human Capital and SMEs performance

Enterprise Goals \& Motives and SMEs performance: While goals could be ascribes as desired results that are gained from behaving in a reasoned way, motivation could be defined as "the process by which goal-directed activities are instigated and sustained" (Teoh \& Chong, 2007; Hasan \& Almubarak, 2016). Motivations of entrepreneurs who start up their businesses are generally classified into two groups: Negative and Positive 
motives, or Push and Pull factors (Sadi \& Al-Gazali, 2012; Hasan \& Almubarak, 2016).

The Push (negative) factors refer to those essential factors (motives) making continuing operations for the entrepreneur is acommitment. Those motives include unemployment; frustration of previous job; financial motives; and flexible work arrangements.

The other group of Pull (positive) motives include achieving aspiration and ambitions; freedom of choice; independence; self-fulfilment; selfachievement; entrepreneurial drive \& desire; social status \& power; and the need for autonomy (self-sufficiency). The current study aims to identify the types of motives that drive SMEs' owners, and to examine the influence of these motives on SME performance. Therefore, the next proposition is formulated:

H3: There is a significant relationship between the Enterprise Goals \& Motives and SMEs performance

Economic Factors and SMEs performance: economic factors refer to the external market conditions that affect the business; and the internal factors related to financing and raising necessary funds for the business (Ekype et al., 2010). Wube (2010) and Hasan \& Almubarak (2016) note that female entrepreneurs encounter several economic obstacles in the form accessing credit and raising necessary funds for their start-ups compared to their male counterparts, particularly in developing economies compared to developed ones. This in turn affect the business performance particularly in its early stages. Accordingly, the following 
hypothesis is proposed to examine economic factors influence on SME performance:

H4:There is a significant relationship between Economic factors and SMEs performance

Socio-cultural Factors and SMEs performance: Social relationships are argued to be critical for the success of entrepreneurial start-ups as they affect the prosperity and growth of the business. These relationships are said to enable entrepreneurs to identify and utilize market opportunities; gather valuable information; mobilize resources; and communicate with customers and vendors. Similarly, culture is also claimed to affect the SME as the perception of the society - that is based on its culture towards SMEs, their ownership portfolio including the gender of the owner, in addition to other factors varying across developing and developed countries. This study assumes that the social and cultural factors surrounding Saudi SMEs will influence their performance. This is reflected in the subsequent proposition:

H5: There is a significant relationship between Socio-cultural factors and SMEs performance

Legal \&Administrative Factors and SMEs performance: these factors include a wide array of issues related to the governmental policies; laws; and regulations that organise business, trade, and commerce within a particular market/country. Javadian \& Singh, (2012) and Hasan \& Almubarak (2016) categorise these factors into three (3) groups, which are: banking rules \& regulations; tax laws; and labour laws. All of the three groups are claimed to significantly affect the performance of all types of businesses in general, and SMEs in particular. Hence the following hypothesis is put for attesting: 
H6: There is a significant relationship between Legal \& Administrative factors and SMEs performance

\section{Design \& Methodology}

This research follows a quantitative methodology to test its six (6)hypotheses and consequently contribute towards answering the research question that was stated earlier. The study used a structured questionnaire to collect empirical data from a convenient sample of the owners of SMEs established and operate in the region of Tabuk, northwest of Saudi Arabia. The instrument consisted of two sections, one belonging to the demographic characteristics of the respondents and their enterprises (e.g. gender; age; marital status; education; past expertise; business sector; age of the enterprise; start-up capital; and enterprise size in terms of number of employees). The second section of the questionnaire consisted of a 5-point Likert scaleto measure the extent of agreement of respondents with a set of statements related to the study's conceptual model (32 statements). The available responses on the scale ranged from $1=$ strongly disagree, to $5=$ strongly agree, where the anchor point of the scale is $3=$ neutral.

All scales were adopted from previous studies, which validated them in either the context of developed economies, or developing economies. Specifically, the studies of Hasan \& Almubarak (2016); Shane (2003); Covin \& Slevin (1989); Bosma et al., (2004); Kuratko et al., (1997); Robichaud et al., (2001); Wube (2010); Teoh \& Chong (2007); and Fatoki (2011) have been used in developing this study's scales. 
For example, the 6-item scale of the EO (Entrepreneurial Orientation) variable was partly adopted from Covin \& Slevin's (1989) study, which was widely used in several other research of EO due to its high levels of reliability and validity (Hasan \& Almubarak, 2016). The 8-item scale of the HC (Human Capital) variablewas partly adopted from the study of Bosma et al., (2004) which examined the variables of work and managerial experiences; education; and professional training. The 3-item scale of the EGM (Entrepreneur Goals \& Motives) variable was operationalized and partly adopted from the motivation variables used in the studies of Kuratko et al., (1997); and Robichaud et al., (2001). The 4-item scale of the EF (Economic Factors) variable operationalization was partly taken from the study of Wube (2010) that focused on several economic factors such as: interest rates; market structure in terms of competition; market accessibility; capital \& finance accessibility; and availability of production resources.

The3-itemscale of the SCF (social \& Cultural Factor) variable was operationalized by adopting the Wube (2010); and Teoh \& Chong (2007) scales that included several factors such as: the effect of social networks; the traditional values and norms; religions; and the struggles to embrace between home and work responsibilities. They also included the influence of parents' occupations; and the support from relatives and friend. The 2 -item scale of the LAF (Legal \& Administrative Factors) variable was operationalized by partly adopting the Wube (2010) study that included several factors such as governmental support; registration \& establishment procedures; 
ownership structure; accessibility to policy makers; labour market; and legislative bodies. Lastly, the operationalization of SME performance variable is partly derived from the studies of Bosma et al., (2004); Fatoki (2011); and Hasan \& Almubarak (2016) using a 6item scale.

Financial and non- financial measures of performance were used, where financial measures include sales and profitability growth. Non-financial measure include the growth in employees numbers; period of survival; the ability to offer higher quality commodities and services; the ability to offer newly developed commodities and services; employees productivity; and social responsibility.

To further evaluate the strength of the questionnaire and the used measures, in-depth interviews were conducted with seven(7) SME owners, and five (5) academics closely working with the SMEs industry literature. Valuable comments were received and the questionnaire was amended accordingly. Consequently, the questionnaire was electronically distributed on the E-mail system of the National Entrepreneurship Institute "RIYADAH" (https:// www. riyadah. com.sa). Riyadah is a governmental establishment that is responsible for incubating, financing, educating, counselling, and training of promising entrepreneurs with (10231) SMEs established across country to date, of which (638) where established in the North western region of Tabuk, and these particular SMEs were e-mailed the final version of the questionnaire. A total of 142 complete and useable questionnaire were submitted back, indicating a response rate of $23 \%$. 
In data analysis, the Statistical Package for Social Sciences (SPSS) ver. 22.0 has been employed, as well as Smart Partial Least Squares (PLS) ver. 2.0. PLS were used because they allow the complete research model to be tested just once (Ringle et al., 2005; Halawi \& McCarthy, 2008; Chiun Lo et al., 2016). At first, SPSS descriptive statistics were employed to analyse respondents' demographic characteristics (Table1). Subsequently, PLS ver. (2.0), which employs path modelling (Chin, 1998; Tenenhaus et al., 2005; Wetzels et al., 2009) was used to measure the model as shown in (Figure 2). The analysis in PLS was twofold, one pertaining to the measurement model, while the other pertains to the structural model. The former involved the assessment of the reliability and validity of the measures, where reliability was assessed by examining the Composite Reliability $(\mathrm{CR})$, and Cronbach's alpha $(\alpha)$ while validity was assessed in the form of convergent validity and discriminant validity. The latter: the structural model test was applied to test to hypothesised relationships between the study's independent and dependent variables.

\section{Findings}

- Demographic profile of respondents

Table 1 shows the demographic information of the 142 respondents. Male respondents counted for $(55.6 \%)$ of the sample.

Table: 1 - Respondents' Demographic Outline

\begin{tabular}{|l|l|c|c|}
\hline \multicolumn{1}{|c|}{$\begin{array}{c}\text { Demographic } \\
\text { variable }\end{array}$} & \multicolumn{1}{|c|}{ Category } & $\begin{array}{c}\text { Frequenc } \\
\text { y }\end{array}$ & Percentage \\
\hline \multirow{2}{*}{ Gender } & MALE & $\mathbf{7 9}$ & $\mathbf{5 5 . 6}$ \\
\cline { 2 - 4 } & FEMALE & $\mathbf{6 3}$ & $\mathbf{4 4 . 4}$ \\
\hline INDUSTRY & SERVICE & $\mathbf{7 5}$ & $\mathbf{5 2 . 8}$ \\
\hline
\end{tabular}




\begin{tabular}{|c|c|c|c|}
\hline & PRODUCTION & 30 & 21.1 \\
\hline & $\begin{array}{l}\text { DISTRIBUTION/AGENCT/ } \\
\text { TRADE }\end{array}$ & 37 & 26.1 \\
\hline \multirow{4}{*}{$\begin{array}{l}\text { ENTERPRISE } \\
\text { AGE }\end{array}$} & LESS THAN 1 YEAR & 63 & 44.4 \\
\hline & 1-3 YEARS & 44 & 31.0 \\
\hline & 3-5 YEARS & 15 & 10.6 \\
\hline & MORE THAN 5 YEARS & 20 & 14.1 \\
\hline \multirow{5}{*}{$\begin{array}{l}\text { OWNER SOCIAL } \\
\text { STATUS }\end{array}$} & SINGLE & 24 & 16.9 \\
\hline & MARRIED & 104 & 73.2 \\
\hline & WIDOWED & $\mathbf{3}$ & 2.1 \\
\hline & DIVORCED & 10 & 7.0 \\
\hline & PREFER NOT TO SAY & 1 & .7 \\
\hline \multirow{5}{*}{ OWNER AGE } & $21-30$ & 43 & 30.3 \\
\hline & $31-40$ & 66 & 46.5 \\
\hline & $41-50$ & 29 & 20.4 \\
\hline & $51-60$ & 2 & 1.4 \\
\hline & OVER 70 YEARS OLD & 2 & 1.4 \\
\hline \multirow{4}{*}{$\begin{array}{l}\text { OWNER } \\
\text { EDUCATION }\end{array}$} & $\begin{array}{l}\text { PRE UNIVERSITY } \\
\text { EDUCATION }\end{array}$ & 34 & 23.9 \\
\hline & $\begin{array}{l}\text { UNIVERSITY } \\
\text { EDUCATION }\end{array}$ & 77 & 54.2 \\
\hline & $\begin{array}{l}\text { POSTGRADUATE } \\
\text { EDUCATION }\end{array}$ & 27 & 19.0 \\
\hline & NOT EDUCATED & 4 & 2.8 \\
\hline \multirow{4}{*}{$\begin{array}{l}\text { OWNERSHIP } \\
\text { TYPE }\end{array}$} & $\begin{array}{l}\text { SOLE OWNERSHIP (1 } \\
\text { OWNER) }\end{array}$ & 93 & 65.5 \\
\hline & $\begin{array}{l}\text { CO-OWNERSHIP ( } 2 \\
\text { OWNERS) }\end{array}$ & 25 & 17.6 \\
\hline & $\begin{array}{l}\text { CO-OWNERSHIP (3 } \\
\text { OWNERS) }\end{array}$ & 12 & 8.5 \\
\hline & $\begin{array}{l}\text { CO-OWNERSHIP (4 OR } \\
\text { MORE OWNERS) }\end{array}$ & 12 & 8.5 \\
\hline
\end{tabular}


More than half the respondents were service companies, and only (25\%) of respondents were enterprises aged more than 3 years, indicating that the majority (75\%) of the sample were SMEs less than 3 years of age.

Most of the owners (73.2\%) were married, and (66.9\%) aged between 3150 years. (54.2\%) had a university education, and (19\%) had a postgraduate degree. $(65.5 \%)$ of the sample were single owned SMEs, and (17.6\%) were jointly owned by two owners.

- Assessment of the Measurement Model

As Table (2) depicts, in order to examine how measurements exhibit sufficient internal consistency, a measurement model is employed to assess construct and individual reliability, as well as discriminant and convergent validity.

Accordingly, confirmatory Factor Analysis (CFA) was conducted. Factor loadings have been employed to assess individual reliability. Carmaines \& Zeller (1979) and Hair et al., (2010, recommendations were followed, noting that factor loadings must be equal to or above (0.70). Most of the factor loadings were above this requirement apart from some items that have been removed. These loadings are significant $(p<0.05)$.

Table: 2 - Results of the Measurement Model

\begin{tabular}{|c|c|c|c|c|}
\hline Item & SFL & $\alpha$ & CR & AVE \\
\hline EO1 & $\mathbf{0 . 6 0 9}$ & & & \\
\cline { 1 - 2 } EO2 & $\mathbf{0 . 5 9 3}$ & & & \\
\cline { 1 - 2 } EO3 & $\mathbf{0 . 4 1 8}$ & \multirow{2}{*}{0.794} & \multirow{2}{*}{0.735} & 0.648 \\
\cline { 1 - 2 } EO5 & $\mathbf{0 . 5 1 9}$ & & & \\
\hline EO6 & $\mathbf{0 . 5 4 9}$ & & & \\
\hline HC1 & $\mathbf{0 . 6 8 5}$ & 0.738 & $\mathbf{0 . 8 1 4}$ & $\mathbf{0 . 6 7 2}$ \\
\hline
\end{tabular}




\begin{tabular}{|c|c|c|c|c|}
\hline HC2 & 0.209 & & & \\
\hline HC3 & 0.567 & & & \\
\hline HC4 & 0.696 & & & \\
\hline HC5 & 0.729 & & & \\
\hline HC6 & 0.639 & & & \\
\hline HC7 & 0.603 & & & \\
\hline HC8 & 0.574 & & & \\
\hline EGM1 & 0.713 & \multirow{3}{*}{0.745} & \multirow{3}{*}{0.740} & \multirow{3}{*}{0.573} \\
\hline EGM2 & 0.723 & & & \\
\hline EGM3 & 0.829 & & & \\
\hline EF1 & 0.651 & \multirow{4}{*}{0.779} & \multirow{4}{*}{0.759} & \multirow{4}{*}{0.60} \\
\hline EF2 & 0.538 & & & \\
\hline EF3 & 0.706 & & & \\
\hline EF4 & 0.753 & & & \\
\hline SCF1 & 0.809 & \multirow{3}{*}{0.770} & \multirow{3}{*}{0.776} & \multirow{3}{*}{0.537} \\
\hline SCF2 & 0.718 & & & \\
\hline SCF3 & 0.465 & & & \\
\hline LAF1 & 0.812 & \multirow{2}{*}{0.814} & \multirow{2}{*}{0.815} & \multirow{2}{*}{0.843} \\
\hline LAF2 & 0.824 & & & \\
\hline EP1 & 0.738 & \multirow{6}{*}{0.790} & \multirow{6}{*}{0.795} & \multirow{6}{*}{0.621} \\
\hline EP2 & 0.440 & & & \\
\hline EP3 & 0.448 & & & \\
\hline EP4 & 0.638 & & & \\
\hline EP5 & 0.440 & & & \\
\hline EP6 & 0.742 & & & \\
\hline
\end{tabular}

Additionally, Table (2) further shows that Cronbach's alpha $(\alpha)$ and the composite reliability (CR) exceed the approved threshold of $(0.70)$. The Average Variance Extracted (AVE) is over the tolerance threshold of (0.50) representing satisfactory convergent validity. Discriminant validity is evaluated by the square root of the AVE, that should be bigger than the correlations between the constructs (Bagozzi \& Yi, 1988; Chin, 1998; 
2010; Gefen et al., 2000; Hair et al., 2010). This condition is satisfied for all construct (Table 3).

Table: 3 - Discriminant Validity of Variables

\begin{tabular}{|c|c|c|c|c|c|c|c|}
\hline & EO & HC & EGM & EF & SCF & LAF & EP \\
\hline EO & $\mathbf{0 . 8 0 1}$ & & & & & & \\
\hline HC & $\mathbf{0 . 5 2 0}$ & $\mathbf{0 . 8 1 9}$ & & & & & \\
\hline EGM & $\mathbf{0 . 4 1 6}$ & $\mathbf{0 . 5 3 6}$ & $\mathbf{0 . 7 5 7}$ & & & & \\
\hline EF & $\mathbf{0 . 4 7 8}$ & $\mathbf{0 . 5 7 2}$ & $\mathbf{0 . 4 5 2}$ & $\mathbf{0 . 7 7 9}$ & & & \\
\hline SCF & $\mathbf{0 . 4 3 3}$ & $\mathbf{0 . 4 1 4}$ & $\mathbf{0 . 3 2 2}$ & $\mathbf{0 . 5 3 5}$ & $\mathbf{0 . 7 3 2}$ & & \\
\hline LAF & $\mathbf{0 . 4 4 0}$ & $\mathbf{0 . 4 8 6}$ & $\mathbf{0 . 2 4 8}$ & $\mathbf{0 . 4 9 3}$ & $\mathbf{0 . 4 3 0}$ & $\mathbf{0 . 9 1 8}$ & \\
\hline EP & $\mathbf{0 . 5 4 2}$ & $\mathbf{0 . 6 7 0}$ & $\mathbf{0 . 4 7 3}$ & $\mathbf{0 . 6 9 5}$ & $\mathbf{0 . 5 5 4}$ & $\mathbf{0 . 6 7 6}$ & $\mathbf{0 . 7 8 8}$ \\
\hline
\end{tabular}

Note. Correlations between variables were all significant $(\mathbf{p}<0.01)$

Note: Square root of AVE on diagonal, while the other entries represent the correlations.

- Assessment of the Structural Model

Figure 2; and Table 4 present the results of the hypotheses testing. All six hypotheses were supported and consequently accepted.

Figure 2 - Results of the Path Analysis

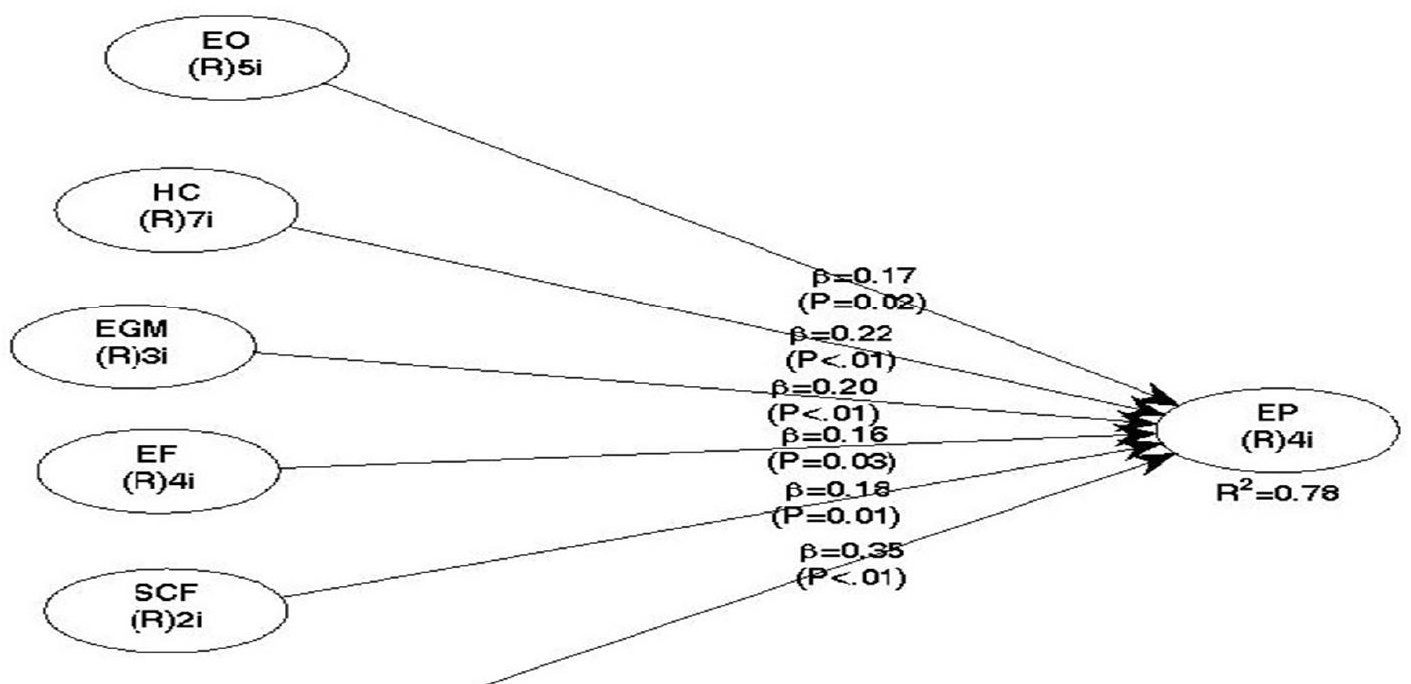


Table 4 - Path Coefficients and hypotheses testing

\begin{tabular}{|c|c|c|c|c|}
\hline Hypothesis & Relationship & $\begin{array}{c}\text { Path } \\
\text { coefficients }\end{array}$ & $\begin{array}{c}\text { p- } \\
\text { value }\end{array}$ & Supported \\
\hline H1 & EO----- Ep & 0.171 & 0.018 & Yes \\
\hline H2 & HC----- Ep & $\mathbf{0 . 2 1 8}$ & $\mathbf{0 . 0 0 4}$ & Yes \\
\hline H3 & EGM----- Ep & 0.196 & 0.008 & Yes \\
\hline H4 & EF----- Ep & $\mathbf{0 . 1 5 6}$ & $\mathbf{0 . 0 2 8}$ & Yes \\
\hline H5 & SCF----- Ep & $\mathbf{0 . 1 7 9}$ & $\mathbf{0 . 0 1 4}$ & Yes \\
\hline H6 & LAF----- Ep & 0.351 & 0.001 & Yes \\
\hline
\end{tabular}

The results of data analysis show significant support of each of the study's propositions. In this regard, hypothesis 1-"There is a significant relationship between Entrepreneurial Orientation EO and SMEs performance" is supported at $\mathbf{p}<0.05$. Similarly, hypothesis 2 -"There is a significant relationship between Human Capital HC and SMEs performance" is supported at $\mathbf{p}<0.05$. Hypothesis 3 - "There is a significant relationship between Enterprise Goals \& Motives EGM and SMEs performance" is supported at $\mathbf{p}<0.05$, and hypothesis 4 - "There is a significant relationship between Economic Factors EF and SMEs performance" is accepted at $\mathbf{p}<\mathbf{0 . 0 5}$. Finally, hypothesis $\mathbf{5}$ - "There is a significant relationship between Socio-cultural Factors SCF and SMEs 
performance", and hypothesis 6 - "There is a significant relationship between Legal and Administrative Factors LAF and SMEs performance" were both supported at $\mathbf{p}<0.05$.

Notably, the results indicate that out of the six independent variables, the Legal \& Administrative Factors (LAF) variable have the strongest positive relationship with the dependent variable at path coefficient $=$ 0.351 .

\section{Discussion}

This study has examined the impact of external and internal success elements of SMEs' performance in the Saudi Arabian context. Six independent variables are claimed to positively influence the dependent variable (i.e. SME performance). Several important notions emerge from the findings, all of which are generally attuned with earlier findings of other scholars. The results add new information to current knowledge by further strengthening and presenting supporting evidence to existing theory of SME performance and success factors particularly in emerging and developing economies.

In this regard, the results indicated that Entrepreneurial Orientation (EO)has a positive influence on the SME performance with statistically significant relationship between the two variables. Consistent with previous research (e.g. Covin \& Slevin's, 1989; Hasan \& Almubarak, 2016), the SME's entrepreneurial orientation in the form of providing innovative and creative products; radically changing the products provided; risk taking; long term planning; clear vision; and opportunity recognition had a significant and positive relationship with SME performance. 
Similarly, it also emerged that Human Capital (HC) is significantly and positively related to SME performance. Human capital is an important organisational resource, and based on the levels of education and experience of workers, SMEs gain significant knowledge that affects different aspects of business performance. While this finding is consistent with what several earlier studies have concluded (e. g. Rosa et al., 1996; Shane \& Vankataraman, 2000; Anderson \& Miller, 2003; Bosma et al., 2004), yet more recent research (e.g. Hasan \& Almubarak, 2016; Chiun Lo et al., 2016) have reported contrary findings. This discrepancy could be justified by the differences in the application context, or due to the fact that HC deficiencies could be overcome and mitigated by other arrangements.

As for the Enterprise Goals \& Motives (EGM) variable, it was noted earlier that the related hypothesis is supported. While goals could be ascribes as desired results that are gained from behaving in a reasoned way, motivation could be defined as the process by which goal-directed activities are started and continued. The findings are consistent with the majority of previous studies that investigated the influence of the EGM on the Enterprise's performance. For example the studies of Shane, (2003); Teoh \& Chong, (2007); Sadi \& Al-Gazali, (2012); and Hasan \& Almubarak, (2016) have all supported this positive association.

With regard to the relationship between Economic Factors (EF)and SME performance, the supported hypothesis is consistent with the studies of Rosa et al., (1996); Wube (2010); and Ekype et al., (2010). Economic factors refer to the external market conditions that affect the business, and the internal factors related to financing and raising necessary funds for the business. 
With regard to the relationship between Social \& Cultural Factors (SCF)and the Performance of the SME, the findings are compatible with previous studies that reported the impressive effect of social factors on the SME performance (e.g. Pirolo \& Presutti, 2010; Javadian \& Singh, 2012; Arasti et al., 2012).

Finally, Legal \& Administrative Factors (LAF) are found to have positively relationship with SME performance, consistent with the studies of Shane, (2003); Ekype et al., (2010); Javadian \& Singh, (2012); Hasan \& Almubarak, (2016). LAF factors include a wide array of issues related to the governmental policies; laws; and regulations that organise business; trade; and commerce within a particular market/country. These factors are classified into three (3) groups: banking rules \& regulations; tax laws; and labour laws. All of the three groups are claimed by literature to significantly affect the performance of all types of businesses in general, and SMEs in particular.

As noted earlier, the strongest association amongst this study's independent variables and the dependent variable is reported for the LAF variable. It can be confidently claimed that these LAF factors are the "make it or break it" factors for the success of SMEs in developing economies in general, and the Saudi Arabian context in particular.

\section{Managerial implications and conclusions}

The study in hand has sought to explore the influence of several success elements on SMEs' performance. Specifically, a set of six factors grouped into internal and external factors were derived from relevant literature, based on the empirical study of Hasan \& Almubarak, (2016) and were put to empirical validation in order to confirm their influence 
on the enterprise's performance (financial and non-financial). The findings revealed that all proposed factors have significant relationship with the performance of the SME, which means that - for example having a higher degree of Entrepreneurship Orientation is more likely to reflect positively on the SME's performance. Likewise, Investing in Human Capital is claimed to result-in favourably on the performance of the enterprise.

When the enterprise's goals and motives are entrepreneurial in nature and aspire creativity; self-actualisation; independence; freedom; and social status, they are likely to impact positively on the performance of the enterprise too.

If the economic, socio-cultural, and legal \& administrative factors are favourable, it is more likely for the SME to succeed and prosper. On the contrary, SMEs' performance is expected to deteriorate if the above factors are less encouraging and prove unfavourable.

Accordingly, several implications are put forward to practitioners. These are:

- There are significant and meaningful associations between this study's independent variables and the performance of the enterprise. These variables are ascribed as success factors that were derived from the literature of SMEs,

- Entrepreneurial Orientation;; Economic Factors Human Capital; Socio-cultural Factors; the Enterprise Goals \& Objectives; and Legal \& Administrative Factors were found by this study to influence the enterprise's performance leading to its success, or failure, 
- Practitioners, i.e. owners, directors, and managers of SMEs have promising opportunities to identify the strengths and weaknesses; the opportunities and threats that face their enterprises in terms of the six success factors elected by this study,

- Investing in human capital, adopting an entrepreneurial orientation, and setting adequate organizational goals and motives are three suggestions related to one half of the study's independent variables. The other half is more relevant to policy makers, legislators, and government officials,

- Policy makers, legislators, and other officials should pay attention to three success factors if the important SME sector is to prosper and flourish. The SME sector is an important catalyst of economic development in national, regional, and international economies. These factors are: Economic Factor; Socio-Cultural Factors; and Legal\& Administrative Factors.

- Special attention should be given to the regulations, policy, laws, and legislations makers whose contribution and influence on SMEs success is evident.

\section{Limitations and recommendations for future research}

Since this study has investigated the SMEs in Saudi Arabia, using a convenient sample from SMEs established and operate in the region of Tabuk, generalisations of the findings to other sectors, contexts, or countries should be treated with care. The use of convenient sampling technique also limits the applicability of findings. Accordingly, academics and researchers are encouraged consider the following points: 
- Researchers are encouraged to put the reported relationships among the study's variables to further validation in other contexts, and by using other sampling techniques,

- Future research could also examine the moderator effect of several variables, such as the gender of the entrepreneur, and the size/sector of the SME,

- Comparative studies with other countries, regions, or industries are encouraged for future research in order to improve understanding of the relationships among the study's variables,

- Other research approaches, such as case studies are important for future research in order to advance our understanding of the research variables,

- Finally, a rather qualitative approach in the form of depth interviews with entrepreneurs, policy makers, and other significant personnel in the SMEs sector should be encouraged in order to induce knowledge and enrich relevant literature.

\section{References}

Arasti, Z., Rezaee, S., Zarei, B. and Panahi, S. (2012), "A qualitative study on individual factors affecting Iranian women entrepreneurs' 
growth orientation", Journal of Management and Strategy, Vol. 3, No. 2, pp. 39-49.

Bagozzi, R. P., and Yi, Y. (1988), "On the evaluation of structural equation models", Academy of Marketing Science, 16(1), 74-94.

Baum, R.J., Locke, E.A. and Smith, K.G. (2001), “A multidimensional model of venture growth", Academy of Management Journal, Vol. 44, No. 2, pp. 292-303.

Benzing, C., Chu, H. and Kara, O. (2009), "Entrepreneurs in Turkey: a factor analysis of motivations success factors and problems", Journal of Small Business Management, Vol. 47, No. 1, pp. 58-91.

Bosma, N., van Prag, R., Thurik, R. and de Wit, G. (2004), "The value of human and social capital investments for the business performance of start-ups", Small Business Economics, Vol. 23, No. 3, pp. 227-236.

Carmines, E. G., and Zeller, R. A. (1979), "Reliability and Validity Assessment", (Vol. 17), Thousand Oaks, CA: Sage.

Chin, W.W. (1998),"The Partial least squares approach for structural equation modelling", In G. Marcoulides (Ed.), Modern methods for business research (pp. 295-336). NJ: Lawrence Erlbaum.

Chin, W.W. (2010), "How to write up and report PLS analyses", In V. Esposito Vinzi, W. W. Chin, J Henseler, \& H. Wang (Eds.), "Handbook of partial least squares: concepts, methods and application", (pp. 645-689). Germany: Springer.

Chiun Lo, M., Wang, Y. C., Wah, C. R. J., and Ramayah, T. (2016), "The critical success factors for organizational performance of SMEs in 
Malaysia: a partial least squares approach", Review of Business Management, Vol. 18, No. 61, pp. 370-391.

Cooper, A., Gascon, J. and Woo, C. (1991), "A resource-based prediction of new venture survival and growth", Academy of Management Proceedings, August, pp. 113-119.

Covin, J. and Slevin, D. (1989), "Strategic management of small firms in hostile and benign environments", Strategic Management Journal, Vol. 10, No. 1, pp. 75-87.

Ekype, I., Mat, N. and Razak, R. (2010), "The effect of microfinance factors on women entrepreneurs' performance in Nigeria: a conceptual framework", International Journal of Business and Social Science, Vol. 1, No. 2, pp. 255-263.

Elenurm, T. and Vaino, E. (2011), "Interpretations of entrepreneurial success factors by female entrepreneurs and executives in a catch-up economy", ICSB World Conference Proceedings, International Council for Small Business (ICSB), Washington, DC, pp. 1-20.

Fatoki, O. (2011), "The impact of human, social and financial capital on the performance of small and medium-sized enterprises (SMEs) in South Africa", Journal of Social Sciences, Vol. 29, No. 3, pp. 193204.

Fornell, C., and Larcker, D. F. (1981),"Evaluating structural equation models with unobservable variables and measurement error", Journal of Marketing Research, 18, 39-45.

Gefen, D., Straub, D. W., and Boudreau, M. (2000), "Structural equation modelling and regression: guidelines for research practice", Communications of the AIS, 4(7), 1-76. 
Gomezelj, D., and Kusce, I. (2013), "The influence of personal and environmental factors on entrepreneurs' performance", Kybernetes, Vol. 42, No. 6, pp. 906-927.

Hair, J. F., Black, W. C., Babin, B. J., and Anderson, R. E. (2010),"Multivariate Data Analysis" (7th ed.): Prentice Hall.

Hair, J.F., Anderson, R.E., Tatham, R.L. and Black, W.C. (2006), "Multivariate Data Analysis with Reading", Prentice Hall, Upper Saddle River, NJ.

Halabi, C.E. and Lussier, R.N. (2014), “A model for predicting small firm performance", Journal of Small Business and Enterprise Development, Vol. 21, No. 1, pp. 4-25.

Halawi, L., and McCarthy, R. (2008),"Measuring students perceptions of blackboard using the technology acceptance model: A PLS approach", E-learning, 26(2), 18.

Hankinson, A., Bartlett, D. and Ducheneaut, B. (1997), “The key factors in the small profiles of small-medium enterprise owner-managers that influence business performance", International Journal of Entrepreneurial Behaviour and Research, Vol. 3, No. 3, pp. 94-98.

Hasan, F.S.A, and Almubarak., M.M.S. (2016), "Factors influencing women entrepreneurs" performance in SMEs", World Journal of Entrepreneurship and Sustainable Development, Vol. 12, No. 2, pp. 82-101.

Javadian, G. and Singh, R. (2012), "Examining successful Iranian women entrepreneurs: an exploratory study", Gender in Management: An International Journal, Vol. 27, No. 3, pp. 148-164. 
Kaplan, R. S., and Norton, D. P. (1996),"The balanced scorecard: Translating strategy into action", Harvard Business Review Press.

Kobeissi, N. (2010), "Gender factors and female entrepreneurship: international evidence and policy implications", Journal of International Entrepreneurship, Vol. 8, No. 1, pp. 1-35.

Kuratko, D., Hornsby, J. and Naffziger, D. (1997), “An examination of owner's goal in sustaining entrepreneurship", Journal of Small Business Management, Vol. 35, No. 1, pp. $24-33$.

Lewrick, M., Omar, M., Raeside, R. and Sailer, K. (2011), "Education for entrepreneurship and innovation: management capabilities for sustainable growth and success", World Journal of Entrepreneurship, Management and Sustainable Development, Vol. 6, No 1/2, pp. 1-18.

Lussier, R.N, Bandara, C.B., and Marom, S. (2016), "Entrepreneurship success factors: an empirical investigation in Sri Lanka", World Journal of Entrepreneurship, Management, and Sustainable Development, Vol. 12, No. 2, pp. 102-112.

Lussier, R.N. (1995), “A non-financial business success versus failure prediction model for young firms", Journal of Small Business Management, Vol. 33, No. 1, pp. 8-20.

Lussier, R.N. (1996a), “A business success versus failure prediction model for service industries", Journal of Business and Entrepreneurship, Vol. 8, No. 2, pp. 23-37.

Lussier, R.N. (1996b), "A start-up business success versus failure prediction model for the retail industry", Mid-Atlantic Journal of Business, Vol. 32, No. 2, pp. 79-92. 
Lussier, R.N. and Corman, J. (1996), “A business success versus failure prediction model for entrepreneurs with 0-10 employees", Journal of Small Business Strategy, Vol. 7, No. 1, pp. 21-35.

Lussier, R.N. and Halabi, C.E. (2010), "A three-country comparison of the business success versus failure prediction model", Journal of Small Business Management, Vol. 48, No. 3, pp. 360-377.

Lussier, R.N. and Pfeifer, S. (2000), "A comparison of business success versus failure variables between US and Central Eastern Europe Croatian entrepreneurs", Entrepreneurship Theory and Practice, Vol. 24, No. 4, pp. 59-67.

National Entrepreneurship Institute "RIYADAH", (https://www.riyadah.com.sa).

Nneka, A. (2015), "Factors that affect the performance of women entrepreneurs in the micro scale enterprises in South-western Nigeria", The Business \& Management Review, Vol. 6, No. 2, pp. 232-239.

Perez, E.H. and Canino, R.M. (2009), "The importance of the entrepreneur's perception of success", Review of International Comparative Management, Vol. 10, No. 5, pp. 990-1010.

Pirolo, L. and Presutti, M. (2010), "The impact of social capital on the start-ups' performance growth", Journal of Small Business Management, Vol. 48, No. 2, pp. 197-227.

Ramos, L., Maldonado, E. and Hernández, E. (2014), "Comparison of women entrepreneurs profiles in Coahuila, Mexico and San Juan, Puerto Rico", Global Conference on Business and Finance Proceedings, Vol. 9, No. 2, pp. 190-200. 
Reynolds, P. and Miller, B. (1989), "New firm survival: analysis of a panel's fourth year", in Brockhaurs, R.H., Churchill, N.C., Katz, J.A., Kirchoff, B.A., Vesper, K.H. and Wetzel, W.E. (Eds), Frontiers of Entrepreneurship Research, Babson College, Wellesley, MA.

Ringle, C. M., Wende, S., and Will, A. (2005),"SmartPLS 2.0.", Hamburg: SmartPLS, (http://www.smartpls.de).

Robichaud, Y., McGraw, E. and Alain, R. (2001), "Toward the development of a measuring instrument for entrepreneurial motivation", Journal of Developmental Entrepreneurship, Vol. 6, No. 2, pp. 189-201.

Rosa, P., Carter, S. and Hamilton, D. (1996), "Gender as a determinant of small business performance: insights from a British study", Small Business Economics, Vol. 8, No. 4, pp. 463-478.

Sadi, M. and Al-Ghazali, B. (2012), "The dynamics of entrepreneurial motivation among women: a comparative study of businesswomen in Saudi Arabia and Bahrain", Asian Academy of Management Journal, Vol. 17, No. 1, pp. 97-113.

Saudi General Authority for Small and Medium Enterprises "Monshaat", (www.monshaat.gov.sa).

Shane, S. (2003), "A General Theory of Entrepreneurship: The Individual-Opportunity Nexus", Edward Elgar.

Shane, S. and Venkataraman, S. (2000), "The promise of entrepreneurship as a field of research", Academy of Management Review, Vol. 25, No. 1, pp. 217-226. 
Slack, N., Chambers, S., and Johnston, R. (2010),"Operations management", Prentice Hall.

Small Medium Enterprises in Saudi Arabia Report, 2016, (www.jeg.org.sa)

Tenenhaus, M., Esposito Vinzi, V., Chatelin, Y. M., and Lauro, C. (2005),"PLS path modelling", Computational Statistics \& Data Analysis, 48(1),

Teoh, W.M.-Y. and Chong, S.-C. (2007), "Theorizing a framework of factors influencing performance of women entrepreneurs in Malaysia", Journal of Asia Entrepreneurship and Sustainability, Vol. 3, No. 2, pp. 1-18.

Wetzels, M., Odekerken-Schroder, G., and van Oppen, C. (2009), "Using PLS path modelling for assessing hierarchical construct models: guidelines and empirical illustration", MIS Quarterly, 33(1), 177196.

Wube, M. (2010), "Factors affecting the performance of women entrepreneurs in micro and small enterprises (the case of Dessie town)", master theses, Department of Educational Planning and Management, Bahirdar University.

Zamberi Ahmad, S. and Xavier, S.R. (2012), "Entrepreneurial environments and growth: evidence from Malaysia GEM data", Journal of Chinese Entrepreneurship, Vol. 4, No. 1, pp. 50-69. 